\title{
KNOWLEDGE, ATTITUDES AND NURSING PRACTICES ON CARDIORESPIRATORY ARREST IN NEONATAL INTERMEDIATE CARE UNIT: A QUALITATIVE STUDY IN THE NORTHEAST OF BRAZIL
}

\author{
Arielle Wignna Brasil Abrantes ${ }^{1}$, Eva Maria Gualberto Coura ${ }^{2}$, André Luiz Dantas Bezerra ${ }^{3}$, \\ Elisangela Vilar de Assis ${ }^{4}$, Ankilma do Nascimento Andrade Feitosa ${ }^{5}$, \\ Maria Aparecida de Freitas ${ }^{6}$, Milena Nunes Alves de Sousa?
}

\begin{abstract}
Introduction: the cardiorespiratory arrest (CRA) in neonates is rarely a sudden event. It is the result of progressive deterioration of respiratory and circulatory functions, leading to irreversible brain damage and death, if appropriate measures are not immediately taken by professionals with specific knowledge. Objective: to analyze the knowledge, attitudes and practices of nursing professionals on cardiorespiratory arrest in a neonatal intermediate care unit. MethodS : Qualitative study of exploratory and descriptive approach, conducted in October 2012 in Cajazeiras, Paraíba, Brazil. Five nurses and three nurse technicians participated. The instrument used was a structured, adapted and validated questionnaire. Results: the nursing professionals knew the definition and how to identify the early signs and symptoms of CRA and recognized the difference between CRA in neonates and adults. Professionals reported changes in care CRA protocol. The careful handling of the newborn, especially the head and neck and heating prior to resuscitation maneuvers were the main actions reflecting basic knowledge to effect the cardiopulmonary ressucitation (CPR) maneuvers. Referring to the sequence of the CPR, questions emerged. Few professionals knew about the correct sequence of the implementation of CPR maneuvers recommended for infants. $100 \%(n=8)$ of the participants demonstrated to know the Advanced Support technical life in neonatology, held with the presence of a doctor. Turning to the main medications administered during CPR in newborns, the adrenaline was the drug of choice, followed by atropine, bicarbonate and dobutamine. Given the factors that hinder the performance of the nursing staff to the CRA victim, professionals reported insecurity, lack of technical skills, difficulty in practice / performance of certain procedures; deficit of practical / theoretical knowledge and inexperience to act on the steps of CPR. Conclusion: it was found that there is no protocol to guide the nursing team in cases of CRA, since they act in a heterogeneous manner. There is also a lack of knowledge of current clinical protocols, on performing certain procedures, primary assessment and chest compressions, according to the new guidelines proposed by the American Heart Association which may lead to a poor quality of care.
\end{abstract}

Key words: heart arrest, nursing, neonatology.

\section{INTRODUCTION}

Cardiopulmonary arrest (CRA) is characterized by the sudden interruption of the heartbeat, breathing movements and immediate loss of consciousness, resulting in irreversible brain injury and death, if the appropriate measures to stabilize the patient are not taken immediately ${ }^{1-2}$.

In infants and children, the CRA rarely is a sudden event, but the result of progressive deterioration of respiratory and circulatory functions ${ }^{3-5}$. Ventricular fibrillation and ventricular

1 Enfermeira. Especialista em Enfermagem em Terapia Intensiva. Cajazeiras, PB, Brasil.

2 Enfermeira. Especialista em Enfermagem em Terapia Intensiva. Cajazeiras, PB, Brasil.

3 Enfermeiro Socorrista do SAMU de Ibiara, PB, Brasil. Especialista em Saúde da Família.

4 Fisioterapeuta. Docente da Faculdade Santa Maria. Doutoranda em Ciências da Saúde pelo Programa de Pós-Graduação Stictu Sensu da Faculdade de Medicina do ABC. Santo André, SP, Brasil.

5 Enfermeira. Docente da Faculdade Santa Maria. Doutoranda em Ciências da Saúde pela Faculdade de Medicina do ABC. Santo André, SP, Brasil.

6 Acadêmica do Curso de Bacharelado em Enfermagem pela Faculdade Santa Maria. Cajazeiras, PB, Brasil.

7 Turismóloga, Administradora e Enfermeira. Docente da Faculdade Santa Maria e das Faculdades Integradas de Patos. Doutoranda em Promoção da Saúde pelo Programa de Pós-Graduação Stictu Sensu da Universidade de Franca. Franca, SP, Brasil.

Corresponding author: arielle_wignna@hotmail.com

Suggested citation: Abrantes AWB, et al. Knowledge, attitudes and nursing practices on cardiorespiratory arrest in neonatal intermediate care unit: a qualitative study in the northeast of brazil. Journal of Human Growth and Development. 25(1): 97-101 Manuscript submitted Jun 18 2014, accepted for publication Dec 202014. 
pulseless tachycardia are the most common cardiac rhythms that influence the CRA in children ${ }^{4}$. Therefore, it is considered an extreme emergency event. The maneuvers of cardio-pulmonary ressucitation (CPR) are immediately needed ${ }^{5}$.

CRA assistance must be effected by health professionals, which must have specific knowledge and skills. Thus, the continuous training is essential, especially to be updated on the most recent guidelines for CRA in infants and children.

In Brazil, about three million children are born annually, among which $10 \%$ require some assistance to the beginning breathing at birth and less than $1 \%$ need extensive resuscitation. The lower the gestational age and/or birth weight, the greater the need of CPR procedures. The Cesare delivery, between 37 and 39 weeks also increases the likelihood of ventilatory support. ${ }^{6}$

The nursing staff plays a key role in health institutions, they are very close to patients regardless of their age, therefore, must have the theoretical and practical knowledge, to perform safely and effectively, the first clinical practices to a patient with CRA. The completion of a CPR determines the suc cess of the entire service, and have repercussions on neonates survival.

Thus, the objective of this study is to analyze the knowledge, attitudes and practices of nursing professionals on cardiorespiratory arrest in a neonatal intermediate care unit.

\section{METHODS}

A qualitative, exploratory and the descriptive research was realized in a Neonatal Intermediate Care Unit (ICU-Neonatal) at Maternity department of Regional Hospital of Cajazeiras, in Paraiba, Brazil. The sample was 12 nursing professionals working in the mentioned unit, among which six were nurses and six nursing technicians. The sample was nonprobabilistic by convenience, established by adaptation to the inclusion and exclusion criteria. Therefore, professionals of the nursing team that had been working in the neonatal ICU for more than 12 months and who agreed to participate in the study by signing the Informed Consent term were included. The professionals who were on vacation, sick leave or transferred to another sector in the period of data collection were excluded.

Five nurses and three nurse technicians met the inclusion criteria ( $66.7 \%$ of the popula-tion). Most team members were women $(87.5 \%, n=7)$ and young $(100 \%, \mathrm{n}=8)$, ranging from 25 to 36 years old. They were graduated over 5 years $(62,5 \% ; n=5)$ and working in the Neonatal ICU between 1 and 2 years $(100 \%, \mathrm{n}=8)$.

Data collection was in October 2012, subsequent to consideration and approval by the Research Ethics Committee of the School Santa Maria, as CAEE 06438612.6.0000.5180. At the time of collection, all professionals were individually informed about the purpose and objectives of the research, and they had the freedom to participate, at no cost or risk, agreeing and signing the informed consent form.
A structured and adapted questionnaire was used to collect the data ${ }^{7}$, which was done a pilot test adjusted to the target population. Data collected were treated according to the premises of Collective Subject Discourse (CSD) technique8, which constitutes a set of keywords that leads to the Central Idea $(\mathrm{CI})$, allowing to determine the knowledge, attitudes and practices of the unit nursing staff on the neonatal cardiorrespiratory arrest and cardiopulmonary resuscitation.

\section{RESULTS}

According the nursing team, the concept of CRA or central idea 1 (CI1) was "cessation of vital clinical signs" and CSD the following expression:

(...) loss or sudden interruption of the cardiovascular system and the cardiorespiratory functions, when the heart stops beating and absence of breathing and heart rate (...) (CSD 1).

The professionals conceptualized as disruption of cardiac and respiratory functions, combining the visual perception of these events to set the time CRA.

Concerning the form of a CRA in newborns, CI1 "clinical evaluation" and CI2 "use of equipment" were observed in speeches:

(...) The sudden loss or interruption of the cardiovascular system, noting the absence of pulsation in the umbilical stump, no expansion of the chest and absence of reflex, central cyanosis and of the extremities (...) (CSD 1). (...) By auscultation and cardiac monitoring, down SPO2 (...) (CSD2).

It was inferred that the professionals associated the identification of CRA in neonates to the verification of vital signs and assessment of the patient's clinical situation through monitoring, as in the use of heart rate monitor, which helps in recognizing the cardiac arrest, but does not represent the criteria for CRA diagnosis.

The nursing team of professionals had the knowledge and was awared on how to identify the early signs and symptoms of CRA, understood as a sudden and abrupt interruption of cardiac, pulmonary and cerebral functions, confirmed by the absence of carotid and femoral pulse, apnea or gasping and lack of responsiveness. ${ }^{3-5}$ In fact, the nursing team must be enabled to identify a CRA or imminent risk of developing it, reestabli-shing cardiac beats early, preventing brain injury ${ }^{3}$.

Concerning the difference between CPR in adults and children, $75 \%(n=6)$ states that "there are differences" and $25 \%(n=2)$ "there is no difference". There is no difference in CRA definition between adults and newborns, but there is difference in etiologic factors that leads the patient to a possible stop ${ }^{4,9}$.

Cardiac arrest in neonates and children is rarely sudden, it is usually the end result of 
respiratory function deterioration or shock, with bradycardia progressing to asystole, as being the most frequent terminal rhythm. 4-6,9,10 Taking all the above into consideration, it is noticed that nursing professionals recognize the difference between cardiopulmonary arrest in infants and in adults.

Concerning the existence of the difference of CPR in adults and in newborns, $100 \%(n=8)$ of those surveyed said "yes." The care of CPR in children has some differences from the adult because of anatomical and physiological peculiarities $^{11}$.

The American Heart Association (AHA) recommends that $\mathrm{CPR}$ in children younger than one year old should be performed compressing the chest with two fingers on the sternum without sudden movements, with compression $4 \mathrm{~cm}$ deep. In children between one and and 8 years old and in adults, the compression must be performed with the hypothenar region of one hand on the sternum, with compression $5 \mathrm{~cm}$ deep ${ }^{12}$.

In neonates, the resuscitation sequence follows the $A B C$ sequence, where $A$ means the process of opening the airways, $B$ means breathing and $\mathrm{C}$ means heart compression, highlighting that the change of this sequence to $C A B$ only is realized when CRA etiology is clearly cardiac. In adults and children, thoracic compressions must start before of rescue breaths ( $C A B$ rather than $A B C$ ). This movement should be repeated with ventilation, so that in adult and children are 30 massage movements for two ventilation, counting at least 100 compressions per minute, performing five cycles. In neonates are three massages for ventilation, totalizing 100 to 120 massage movements per minute, pressure should be exercised only with the second and third fingers or with both thumbs in the lower $1 / 3$ of the sternum.

Regarding knowledge of the changes in CRA services according to the AHA protocol 13, the CI obtained were: "CPR maneuvers sequences" (CI1), "breathing pattern" (CI2) and "cardiac compressions" (CI3), observed in the following statements:

(...) Change in $A B C$ sequence for the $C A B$. Now begins CPR with compressions and no longer by opening the airways (...) (CSD1).

(...) Elimination of see, hear, feel; avoid excessive ventilation (...) (CSD2).

The professionals reported changes in CRA protocol. For CPR and Cardiovascular Emergency Care, there was a change in the sequence BLS procedures from $A B C$ to $C A B$, applicable in adults, children and babies, excluding newborns, prioritizing at least 100 compressions per minute, in order to provide blood flow as quickly. The "see, hear and feel" if there is breath after opening the airways was removed from the CPR sequence. ${ }^{13}$

Aiming to identify nursing team care before CPR maneuvers in newborns, the following CI were obtained: "proper handling" (CI1), "monitoring" (CI2) and "sector organisation" (CI3), with the reports:
(...) Resuscitation material prepared in an easily accessible place, ready to be used (...) (CSD3).

Care for the newborn handling, especially with the head and the neck and heating before the resuscitation maneuvers were the main actions reflecting basic knowledge to effect the CPR maneuvers. Another point highlighted was to maintain airway patency, positioning the head of newborns with mild extension of the neck, avoiding hyperextension. Next, if there are excessive airway's secetions, the mouth and the nostrils are delicately aspirated with a tracheal tube connected to a vacuum aspirator, under maximum pressure, approximately $100 \mathrm{mmHg}^{3-6,9-11}$.

The need to evaluate the vital signs and recognition of changes to start CPR maneuvers were also verified. The Heart rate $(H R)$ is the main indicator factor for CPR maneuvers. Post birth, the newborn must breathe regularly enough to keep the HR above $100 \mathrm{bpm}$, so once done the initial steps of resuscitation, the respiratory rate is evaluated (RR) and the HR. If there is appropriate vitality, with rhythmic and regular breathing and $\mathrm{HR}>100 \mathrm{bpm}$, the newborn should receive routine care in the delivery room. If after the initial steps it shows no improvement, positive pressure ventilation is indicated. . $^{411}$

Also, before starting CPR, it is necessary to maintain the organization's environment and material resources (intended to maintain the temperature, airways aspiration, ventilation and drug administration) to be used, which must be prepared, tested and available in an accessible place. ${ }^{7}$

Although such aspects are indispensable, the actions must be humanized, because the "humanization of neonatal care is a necessary element for the reorganization of health practices", 14,28 independent of assistance in a critical situation or not.

Referring to the sequence of CPR, doubts emerged $50 \%(n=4)$ states that the correct sequence consists in heart compression, artificial respiration and airway maintenance; $25 \%(n=2)$ indicated the following: airway maintenance, cardiac compression and artificial respiration and other $25 \%$ ( $n=2$ ) highlighted as order: airways maintenance, artificial respiration and cardiac compression.

Few professionals showed to know about the correct sequence of CPR maneuvers recommended for newborns, demonstrating unawareness and absence of an institutional protocol to ensure the quality of care.

About changes in the AHA guidelines in CPR, professionals should be updated about the last revised version of those clinical practice guidelines to act accordling, in order to improve and ensure the quality of care. Therefore, differently from the changes in the adult protocol, ${ }^{13}$ the resuscitation sequence recommended for neonates was not changed, following $A B C$, where A means the process of opening the airways, B means breathing and $C$ means heart compression, highlighting that the change to the CAB only is realized when CRA etiology is clearly cardiac. 
Regarding the knowledge on the Advanced Life Support (ALS) in Neonatology, 100\% $(n=8)$ of the participants stated that it consists in: intubation, ventilation, ensuring venous access, monitoring and administration of medication, demonstrating that professionals had knowledge in ALS techniques, held with the Physician.

The ALS refers to the evaluation and respiratory and circulatory continuity, improving the maneuvers used in Basic Life Support V round (BLS), performing special equipment and techniques to detect arrhythmias after electrocardiographic monitoring, tracheal intubation, obtaining and maintenance the access, use of drugs and treatment in conditions related to CRA 9. Therefore, the ALS is the junction of BLS to the use of adjuvant therapy to maintain appropriate ventilation.

The association of CPR maneuvers with drugs and technology promotes the restoration of spontaneous circulation, heart rate regularization and contributes to satisfactory functioning of the cardiorespiratory system ${ }^{15}$.

Regarding to the main medications administered during the CPR in neonates, 36\% $(n=8)$ cited adrenaline, $22 \%(n=5)$ volume expanders; $9 \%(n=2)$ atropine, bicarbonate, and dobutamine, each; $5 \%(n=1)$ glucose, calcium and dopamine, each.

Adrenaline was the drug chosen, followed by atropine, bicarbonate and dobutamine. The other medications were little mentioned, which may indicate underutilization. Thus, the professional must know all the drugs to be used during CPR.

\section{REFERENCES}

1. Souza SFM, Silva GNS. Parada cardiorrespiratória cerebral: assistência de enfermagem após a reanimação. Rev Ciênc Saúde. 2013; 11(2): 143-57.

2. Pazin Filho A, Santos JC, Castro RBP, Bueno CDF, Schmidt A. Parada cardiorrespiratória (PCR). Medicina. 2003; 36:163-78.

3. Neves DD, Fey A. A auto-percepção do enfermeiro no atendimento a PCR em pediatria de uma instituição hospitalar. Rev Caminhos. 2011; 2(3):7-25.

4. Kleinman ME, Chameides L, Schexnayder SM, Samson RA, Hazinski MA, Atkins DL, et al. 2010 American Heart Association Guidelines for Cardiopulmonary Resuscitation and Emergency Cardiovascular Care. Circulation. 2010; 122(18):876-908. Doi: 10.1161/CIRCULATIONAHA.110.971101.

5. Matsuno AK. Parada cardíaca em crianças. Medicina (Ribeirão Preto) 2012;45(2): 223-33.

6. Margotto PR, Wing O. Reanimação Neonatal. Consenso Internacional 2010 em Reanimação Cardiopulmonar e Cuidados Cardiovasculares de Emergência com Recomendações de Tratamento. Circulation. 2010; 122;516-38.

7. Coura EMG. Parada cardiorespiratória em pediatria: conhecimento da equipe de enfermagem no atendimento pré-hospitalar [monografia]. Cajazeiras (PB): Universidade Federal de Campina Grande; 2011.
Among them, adrenaline, lidocaine, naloxone, sodium bicarbonate, chloride or calcium gluconate and glucose are the most highlighted during CPR in neonates in the literature. However, sodium bicarbonato, naloxone and vasopressors are not recommended in the delivery room ${ }^{16}$.

Facing the factors that difficult the nursing team performance in BLS and ALS to CRA victims, professionals reported insecurity, lack of technical hability, difficulty in performing certain procedures of $8 \%(n=1)$ each; deficit of practical / theoretical knowledge ( $53 \% ; n=7)$ and inexperience to perform CPR steps $(23 \% ; n=3)$. Professional inexperience, lack of attention and lack of technicalscientific knowledge were cited as determining factors for the failure of a resuscitation in a study on iatrogenicity in CPR conducts ${ }^{6}$.

It is clear that dealing with urgent / emergent situations generates apprehension and difficulties in assistance. However, it might be resolved with training.

\section{CONCLUSION}

It was found that there is no protocol to guide the nursing team in cases of CRA, since they act in a heterogeneous manner. There is also a lack of knowledge on current protocols and on performing certain procedures, primary assessment and chest compressions, according to the new guidelines proposed by the American Heart Association which may lead to a poor quality of care.

8. Lefevre F, Lefevre AMC, Araújo SDT, Cornetta VK. O discurso do sujeito coletivo como eu ampliado: aplicando a proposta em pesquisa sobre a pílula do dia seguinte. Rev Bras Crescimento Desenvolvimento Hum. 2010; 20(3):798-808.

9. Cardoso RCA. Falência cardiopulmonar em paciente pediátrico. Rev Pediatr SOPERJ. 2010; 13(2);14-20.

10. Kattwinkel J, Perlman JM, Aziz K, Colby C, Fairchild K, Gallagher J. et al. Neonatal resuscitation: 2010 American Heart Association Guidelines for Cardiopulmonary Resuscitation and Emergency Cardiovascular Care. Pediatrics. 2010; 122(5): e1400-e1413. Doi: 10.1542/ peds.2010-2972E)

11. Kleinman ME, Caen AR, Chameides L, Atkins DL, Berg RA, Berg MD, et al. Pediatric Basic and Advanced Life Support: 2010 International Consensus on Cardiopulmonary Resuscitation and Emergency Cardiovascular Care Science With Treatment Recommendations. Circulation. 2010; 122(16): S466-515.Doi: 10.1161/CIRCULATIONAHA.110.971093

12. Wyckoff MH, Salhab WA, Heyne RJ, Kendrick $D E$, Stoll BJ, Laptook AR, et al. Outcome of extremely low birth weight infants who received delivery room cardiopulmonary resuscitation.] Pediatr. 2012; 160(2): 239-44. Doi: 10.1016/ j.jpeds.2011.07.041

13. Silva SC, Padilha KG. Parada cardiorespiratória na unidade de terapia intensiva: considerações 
teóricas sobre os fatores relacionados às ocorrências iatrogênicas. Rev Esc Enferm USP. $2001 ; 35(4): 360-5$.

14. Rocha DKL, Ferreira HC. Estado da arte sobre o cuidar em neonatologia: compromisso da enfermagem com a humanização na unidade de terapia intensiva neonatal. Enferm Foco. 2013; 4(1):24-8.

15. Zanini J, Nascimento ERP, Barra DCC. Parada e reanimação cardiorrespiratória: conhecimentos da equipe de enfermagem em Unidade de Terapia Intensiva. Rev Bras Ter Intensiva. 2006; 18(2):143-7. Doi:10.1590/S0103-507X2006 000200007.

16. Almeida MF, Guinsburg R. Programa de reanimação neonatal da Sociedade Brasileira de pediatria: condutas 2011. [cited $2013 \mathrm{Jul} 11$ ] Available from: http://www.sbp.com.br/pdfs/ PRN - SBP-ReanimacaNeonatal- 2011 24jan11.pdf.

\section{RESUMO}

Introdução: em lactentes a parada cardiorrespiratória raramente é um evento súbito. Trata-se do resultado da deterioração progressiva da função respiratória e circulatória, acarretando em lesão cerebral irreversível e morte, caso as medidas adequadas para estabilizar o paciente não sejam tomadas imediatamente por profissionais que possuam conhecimentos e habilidades específicas. Objetivo: analisar os conhecimentos, atitudes e práticas de profissionais da equipe de enfermagem atuante em unidade de cuidados intermediários de neonatologia sobre a parada cardiorrespiratória. Método: pesquisa qualitativa, de caráter exploratório e descritivo, realizada no município de Cajazeiras-PB, Brasil em outubro de 2012. Participaram do estudo cinco enfermeiros e três técnicos de enfermagem. Para coleta de dados foi utilizado um questionário estruturado e adaptado. Resultados: os profissionais da equipe de enfermagem sabiam o que era e como identificar os primeiros sinais e sintomas da PCR, bem como reconheciam a diferença da PCR em neonatos e adultos. Os profissionais relataram as alterações no protocolo de atendimento a PCR. O cuidado com o manuseio do recém-nascido, especialmente com a cabeça e o pescoço e o aquecimento antes da realização das manobras de reanimação foram as principais ações refletindo conhecimento básico para efetivar as manobras de RCP. Reportando-se à sequência da RCP, dúvidas emergiram. Poucos profissionais demonstraram conhecer a sequência correta da execução das manobras de RCP preconizadas para o RN. $100 \%(n=8)$ dos participantes demonstraram conhecer as técnicas de Suporte Avançado de Vida em neonatologia, realizadas com a presença de um médico. Quanto às principais medicações administradas durante a RCP em neonatos, a adrenalina foi o fármaco de escolha, seguidos pela atropina, o bicarbonato e a dobutamina. Diante dos fatores que dificultam a atuação da equipe de enfermagem à vítima de PCR, os profissionais relataram insegurança, falta de habilidades técnicas, dificuldade na prática/realização de certos procedimentos; déficit de conhecimento prático/teórico e inexperiência para atuar nas etapas da RCP. Conclusão: constatouse a inexistência de um protocolo para orientar a equipe em casos de PCR, pois os mesmos relataram agir de forma heterogênia. Além disso, foi constatada a insuficiência de conhecimentos sobre protocolos atuais, bem como despreparo ao realizar determinados procedimentos, avaliação primária e realização das compressões torácicas de acordo com as diretrizes propostas pela American Heart Association.

Palavras-chave: parada cardíaca, enfermagem, neonatologia. 